\title{
Left Against Medical Advice
}

National Cancer Institute

\section{Source}

National Cancer Institute. Left Against Medical Advice. NCI Thesaurus. Code C99969.

A designation that a patient has chosen not to heed the directions that medical staff has

advised, and has chosen to leave the facility. 